\title{
Issue in Information Sharing of Halal Food Supply Chain
}

\author{
Nor Ratna Masrom ${ }^{1}$, Raja Zuraidah Rasi $^{2}$, Badru At Tamam Daut ${ }^{3}$ \\ ${ }^{1}$ Faculty of Technology Management and Technopreneurship, Universiti Teknikal Malaysia Melaka, \\ Melaka, Malaysia. \\ ${ }^{2,3}$ Faculty of Technology Management and Business, Universiti Tun Hussein Onn Malaysia, Johor, \\ Malaysia.
}

\begin{abstract}
Information sharing serves as an essential approach for the companies and antecedents of supply chain integration. Nowadays, with the highly competitive in halal food market, information sharing has become more conceivable. Furthermore, information sharing in supply chains has become more efficient by having meaningful relationship with the members of halal supply chain. There is a lack information regarding information shared within members in halal food supply chain literature. The information needed in order to shed the light of how companies nowadays can be more competitive. The purpose of this study is to investigate to what extent the information can be shared among the members of the halal food supply chain. This study elaborates the barriers of information sharing leading to enhanced supply chain integration among enterprises, as a result. The interview with four managers from halal certified food manufactures has been deployed to get rich data about the information sharing. The finding shows that most of cases halal certified food manufacturers has low communication with their suppliers. Trust is the key enablers within the members of halal food supply chain.
\end{abstract}

\section{Introduction}

Today's world offers opportunity to the organizations. Currently, the rising of Muslim population in the world has made the halal sector as one of promising profit. Malaysia is one of the halal food produces in the world. In order to survive and compete in halal sector, halal certified food manufacturing sector strongly needs to create, share and disseminate up-to-date and appropriate knowledge and information. A halal supply chain should connected by flows of information, finance and material by the suppliers, manufacturers, retailers, distributors and customers. Information sharing among supply chain partners creates information flow within supply chain management and this enables supply chain partners to make decision effectively. Information sharing is an important element that reflects cooperation in supply chain management, according to $\mathrm{Li}$, Yan, Wang and Xia (2005). According to Simatupang and Sridharan (2002b), information sharing is "the ability to see private data in a partner's systems and monitor the progress of products as they pass

\footnotetext{
*Corresponding author: norratna@utem.edu.my
} 
through each process in the supply chain. This activity includes monitoring (data capturing), processing, and dissemination of customer data, end-to-end inventory status and locations, order status, costs-related data, and performance status". These authors have argued that information sharing ensures that partners in the supply chain are able to fulfill demand within shorter order cycle times based on the shared information. Information systems improve the quality of forecasting, decision, planning and control, mitigate the risk caused by the external market environment and internal factors of the supply chain, and consequently improve the efficiency and effectiveness of supply chain operations.

However, there are always doubt about sharing information with trading partners due to the perceived complexities, risks, and costs (Kembro and Näslund, 2014). Willingness to share commercially sensitive information with trading partners is crucial if end-customers are to be completely satisfied and the total costs to the supply chain minimized (Ellinger et al., 2012; Yu et al., 2013).

Hence, an understanding of managers' perceptions of the information shared, the issues and to what extent information sharing is key to gaining deeper insights into the information- sharing process.

Tan et al 2015, said that information sharing will increase profit from reducing uncertainty and improve efficiency and effectiveness. Halal food sector is very competitive and it is asking halal certified food manufacturers to collaborate with other supply chain members in order to sustain as a world leader of halal food producer. The specific research questions are

RQ1. What information is shared across supply chain interfaces?

RQ2. What are the issues related to information sharing in halal food supply chain?

RQ3. To what extent that information can be shared in halal food supply chain?

\section{Literature Review}

Information sharing within business units and across supply chain partners such as suppliers and other strategic alliances is essential. Information sharing develops three major linkages known as the supplier linkage, internal linkage, and customer linkage. Integration through an effective and efficient information flow will eventually lead to a better performance of the firm and total supply chain to (Narasimhan and Kim, 2002; Palsson and Johansson, 2009; Lee et al., 2007). Past studies (Du, 2007; Gunasekaran and Ngai, 2004; Kim and Narasimhan, 2002) reported positive relationships between the level of information flow integration and performance. As such increasing the level of integration and information sharing among the supply chain members is necessary to improve the effectiveness of the supply chain. (Sezen, 2008; Trkman et al., 2007).

Halal food supply chain is a process of managing the procurement, movement, storage and handling of material parts, livestock, semi-finished or finished inventory both food and non-food, and related information and documentation flows through the organization and the supply chain in compliance with the general principles of Sharia law.

Muslims represent an estimated $23 \%$ of the global population or about 1.8 billion consumers with an average growth rate of $3 \%$ per annum. If the trend continues, Muslims will be $26 \%$ of the world's total projected population of 2.2 billion in 2030 . 


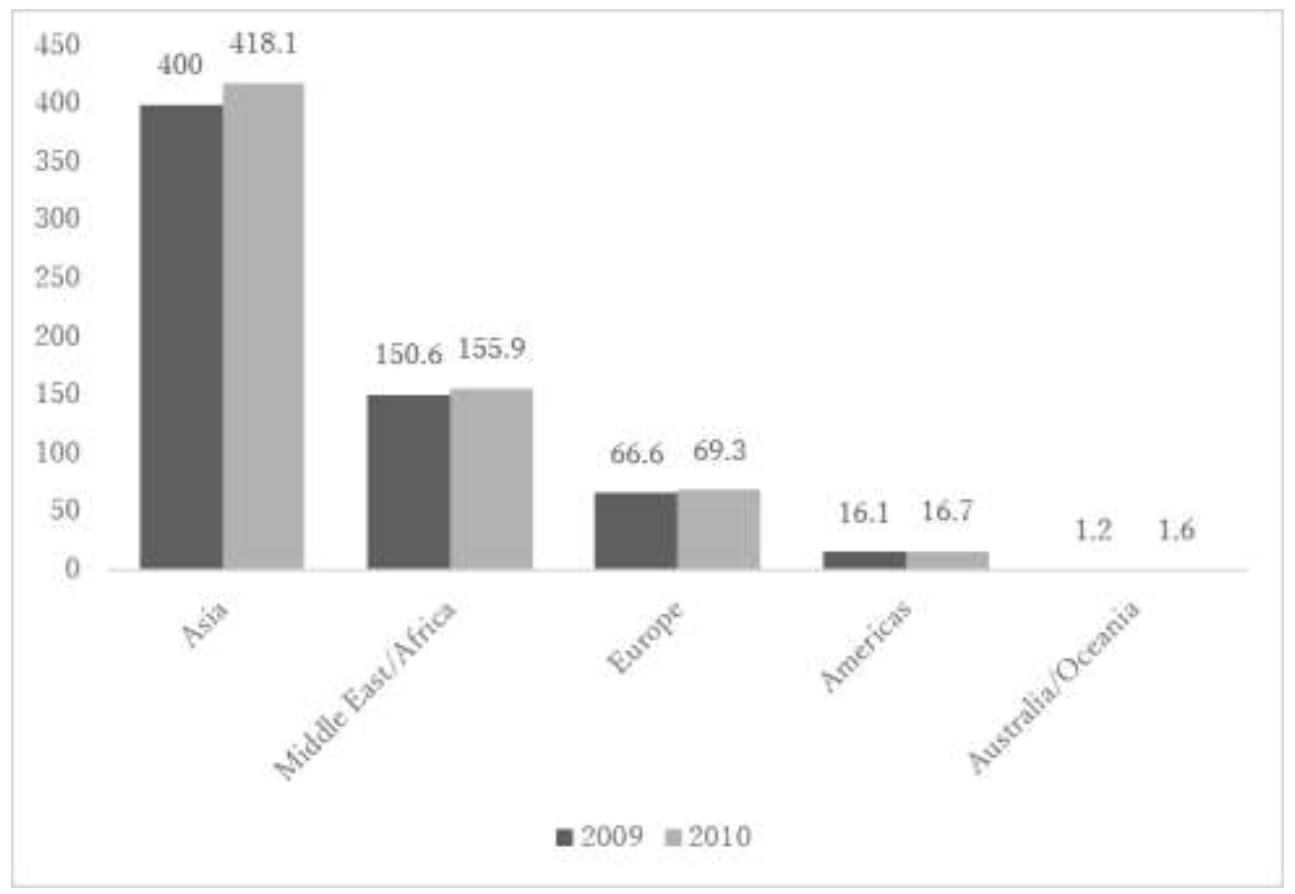

Figure 1: Global halal food market size by region

Source: World Halal Forum 2009 Post Event Report and the 6th World Halal Forum Presentation

The number in Figure 1 shows that halal industry is one of the fastest growing markets in the world. Halal market is not limit to Muslim only but it has been accepting by the nonMuslim. The demand for the halal certified products has gain popularity among them due to high quality, safe and ethical products. Halal food market has been estimated around USD667 million and represents $20 \%$ of the entire global food industry. Many economists believe that based on four prevalent trends. Firstly, Islam is now the fastest growing religion in the world thus it will make big global demand for halal products. The annual growth in consumption of halal food is estimated at $16 \%$. Secondly, the growing trend of consuming. Next the halal consumer power has been increasing because of the increasing number of Muslim and rising of their disposable income. Lastly, the increasing of awareness of consuming halal food among Muslims

Halal food is becoming an increasing part of the Western diet and has become a multibillion-dollar global industry involving multinationals like Tesco, Unilever and Nestle who have aggressively expanded their halal-certified product lines. Halal is originated from Arabic word which means lawful and permissible according to Islamic Sharia law which refers to the teachings of Al-Quran and exemplary conduct of Prophet Muhammad (Peace and blessings of Allah be upon Him) as quoted in Hadith. The opposite of Halal is Haram which means forbidden, Roland (1996).

\section{Methodology}

This research was using a multiple case study approach (Yin 2003) to help explain manager perceptions of the challenges and security risks involved when exchanging information with other supply chain actors, tested in the first phase. Because the goal of the second, qualitative, phase was to explore and elaborate on the results from the first, quantitative, 
phase of the study (Creswell et al. 2003) information sharing were significant predictors of operational performance among halal certified food manufacturers in Malaysia. This qualitative phase is using multiple case study. Where case study is an exploration of a bounded system or a case over time through detailed, in-depth data collection involving multiple sources of information and rich in context (Merriam 1998). This method is an ideal to find deeper knowledge experience of practitioners in these emergent fields (Walsham, 1995). This phase has more than once case and the analysis involved two levels: within each case and across the cases (Stake 1995; Yin 2003).

The sample is purposive sampling of firms. Purposive sampling able to meet the objective of the research due to relevant characteristics for the research questions (Bryman and Bell, 2011). For the data collection, this research has collected the data from four participants. They are managers in halal certified food manufacturers in Malaysia that has involved in survey before. They have been selected because

1. They are responsible in exchanging information with supply chain members

2. They understand the process of halal food supply chain management in Malaysia

Furthermore, the purpose of selecting these respondents because to capture their experiences and thereby increase the validity and reliability of findings. And it is most likely to be the most informative sources.

It is focused on the data exchange between a case study and its main suppliers and retailers/distributors. Besides that, this phase also tend to understand the complex phenomena and contextually rich settings, as proven the current state of knowledge of each discipline being characterized as "at an early formative development stage and subject to rapid change” (Zsidisin, 2003). Table 1 provides a case company overview

\subsection{Data Collection}

This research used sources for collecting the data that will provide the richness and the depth of the case description (Stake 1995) including qualitative interviews triangulated with secondary sources. The participants has vast experience and knowledge of supply chainrelated operations in halal food in Malaysia. Each interview usually has three stage of questioning as suggested from Seidman 2006. In this research the three stages are; description of information shared among the members in halal food supply chain, description of issues in information sharing and description of to what extent that information should be shared in halal food supply chain. Fieldwork has been done before the interviewing process. This is to understand the situation of the halal food activities and increase the validity of the research. The pilot test has been deployed to help to test the aspects of a final research. One manager from halal certified food manufacturer was voluntarily to see the clarity of the questions.

After the pilot, the appointment has been made before hand to set time and location of the interview process. All of the respondents preferred their office. The choice of location is really important because it is helping to get more information from the interview process. The time length of interviewing was between 35-75 minutes. The use of semi-structured interview and follow up questions has encouraged the flexibility in interview procedure. This procedure helps the research to get more information that relates to the objective of the central construct (Bryman and Bell, 2011). At the same time, the secondary sources has been referred. The secondary source including the including standard operating procedures and mission statements of each the case company. 
Table 1: A case company overview

\begin{tabular}{|l|l|l|l|l|l|}
\hline Case (company) & $\begin{array}{l}\text { Function of } \\
\text { respondent }\end{array}$ & $\begin{array}{l}\text { Interview } \\
\text { duration } \\
\text { (min) }\end{array}$ & $\begin{array}{l}\text { Date of } \\
\text { interview }\end{array}$ & location & products \\
\hline Manufacturer 1 & Manager & 75 & $\begin{array}{l}20 \text { March } \\
2017\end{array}$ & $\begin{array}{l}\text { their } \\
\text { office }\end{array}$ & noodles \\
\hline Manufacturer 2 & $\begin{array}{l}\text { Managing } \\
\text { director }\end{array}$ & 40 & $\begin{array}{l}23 \text { March } \\
2017\end{array}$ & $\begin{array}{l}\text { their } \\
\text { office }\end{array}$ & $\begin{array}{l}\text { Coco } \\
\text { products }\end{array}$ \\
\hline Manufacturer 3 & $\begin{array}{l}\text { Managing } \\
\text { director }\end{array}$ & 35 & $\begin{array}{l}25 \text { March } \\
\text { their } \\
\text { office }\end{array}$ & $\begin{array}{l}\text { Virgin } \\
\text { coconut } \\
\text { oil }\end{array}$ \\
\hline Manufacturer 4 & Sales manager & 40 & $\begin{array}{l}27 \text { March } \\
2017\end{array}$ & $\begin{array}{l}\text { their } \\
\text { office }\end{array}$ & $\begin{array}{l}\text { Seafood } \\
\text { products }\end{array}$ \\
\hline
\end{tabular}

\subsection{Data analysis}

The data has been recorded, transcribed and coded as proposed by Yin 2009. Yin also emphasizes that the analysis of the qualitative data utilized an explanation building process proposed. Then it will develop the finding through a series of iterations. Every participants were assigned to a generic name as in Table 1 and number to preserve anonymity.

Data analysis started with within-case analysis. This analysis to figure out description of information shared among the members in halal food supply chain, description of issues in information sharing and description of to what extent that information should be shared in halal food supply chain. Then followed by cross-case analysis to identify similar/contrasting themes and patterns. The data also has been verified through triangulating different sources of information and member checking (Creswell 2002).

\section{Data Findings}

RQ1. What information is shared across supply chain interfaces?

Table 2: Summary of information shared

\begin{tabular}{|c|c|}
\hline Case company & Types of information shared \\
\hline Manufacturer 1 & $\begin{array}{c}\text { Place and received orders from supplier, product related } \\
\text { information, some forecasting, delivery schedule }\end{array}$ \\
\hline Manufacturer 2 & $\begin{array}{c}\text { Requirement for materials, forecasting, product related } \\
\text { information, sales history }\end{array}$ \\
\hline Manufacturer 3 & $\begin{array}{c}\text { Feedback on products quality and price, requirement for } \\
\text { materials, Place and received orders, some forecasting }\end{array}$ \\
\hline Manufacturer 4 & $\begin{array}{c}\text { Marketing-related information, some forecasting, Place and } \\
\text { received orders }\end{array}$ \\
\hline
\end{tabular}

Table 2 above shows the range of information that is being shared with the members in halal food supply chain in Malaysia. Most cases they shared is operational data such as delivery schedule, requirement for materials, some forecasting and feedback on products.

Most of the halal certified food manufacturers in Malaysia shared the information of their orders with their main suppliers. As a manufacturer 1 said 
"We just place and received orders from supplier but not further communication. We specify our order to them specifically, the expected time arrival and quantity of the materials. When they send the wrong one, we will reject the orders"

Forecasting is very important in food supply chain because food is perishable product. Halal certified food manufacturers get the forecast from their customers (retailers/distributors) and shared to their supplier so that the supplier will prepare and deliver the raw material on right time and right quantity. Manufacturer 2 mentioned

"Our distributors always tell us the quantity that we are supposed to produce next week. Because our distributors are the closest to customers and they have been in this market for long period of time"

Due to stringent policy in halal food production, relevant information in the order is the policy that control the process and the quality of the process. As manufacturer 3 articulated

"In the order, we told them that we are producing halal food. So they must also comply with MS1500 procedure and their certificate is not expired"

To summarize, within case analysis emphasizes the types of information shared to every case company has been figured out and supported by Huang et al (2003). Huang et al (2003) specified that there are six categories of production information are often shared: product, process, resource, inventory, order and planning. Specifically, most of cases in halal certified food manufacturers shared process information with their main supplier. The process information includes lead time, the policy that control the process and quality of the process. This can be shown from the process of ordering and receiving materials. The ordering starts with the placement of the order and supplier agree to supply at certain amount on specific date. Besides the quantity and time, the relevant information are lead time in ordering and delivering the raw material and their expected quality.

Meanwhile, most of the halal certified food manufacturers in Malaysia shared order information with their retailers and distributors. They have better relationship with their retailer/distributor compare with supplier. The demand information flow from end customers to the supplier that creates forecasting and sales history. Lee et al (1997) showed that demand has an impact on the bullwhip effect. So, if they get the right information sharing the bullwhip effect will be decreased.

RQ2. What are the issues related to information sharing?

Table 3: Case by case summary of the issue information sharing

\begin{tabular}{|l|l|}
\hline Case company & Issues \\
\hline Manufacturer 1 & Supplier does not care about us. Supplier just send order \\
\hline Manufacturer 2 & $\begin{array}{l}\text { Supplier sometimes send the wrong products and it delayed my } \\
\text { production process }\end{array}$ \\
\hline Manufacturer 3 & $\begin{array}{l}\text { Supplier did not send the product on time especially in peak } \\
\text { season due to high demand from competitors }\end{array}$ \\
\hline Manufacturer 4 & Suppliers do not share information about the stock level \\
\hline
\end{tabular}

The Table 3 above summarizes the interview data describing the issues related to information sharing. Most of respondents concern about their relationship with their suppliers. They do not have meaningful relationship with their suppliers. Manufacturers 1 mentioned as below 
"We called our supplier many times to place in order but they hardly pick up my calls, I just place order and they send my order"

Furthermore, without meaningful relationship the uncertainty from the trading partner will result to inconsistent supplies in customer side as stated by manufacturers 2

"The distributor change their preference supplier without telling us..."

In order to secure their position, they have to deliver the right product on the right time. They have to guarantee their quality and freshness of the food. As manufacturer 1 said

"By hook or by crook, I have to fulfill the demand from my customers, if not, my business will be doomed"

In summarization, the main issue is to have meaningful relationship among the members in halal certified food manufacturers in Malaysia. With meaningful relationship, the uncertainty will be reduced. In addition, the information flow within halal food supply chain members also reduce the impact of bullwhip effect.

RQ3. To what extent that information can be shared?

The willingness of information sharing is depends on trust. As articulated by manufacturer 1 ,

"Trust is very important. If the distributor does not trust me, they will not share the information and business will face difficulty"

"Do you want to share your information without trusting them? I rather not"

The above statement has been mentioned by manufacturer 4, again shows that trust is very important in information sharing. If the trading partner agree to share their information, they have to restructure their information to be available in making good decision. Even though, they are willing to share their information but there are few things they still keep confidential if they have unique special process flow to produce their products or secret ingredients that can differentiate their product from others.

\section{Mentioned by manufacturer 4}

"I told my customer my ingredients and where I get my materials. However, I kept the process of how to produce my product because that is my marketing value"

Stated by manufacturer 3

"My kept my secret ingredients but do not worry, everything is halal compliance"

In summary, trust plays an important roles to what extent that the information can be shared among the members in halal food supply chain. The trust can be built through personal relationship and long-term collaboration that involved honesty. However, even though there is trust but if they have special process flow or special ingredients they will not share it to the trading partners. 


\section{Discussion}

The members of supply chain place order decision based on the order received from downstream and member's own policy and forecast as in Huong et al (2003). This phenomena also happened in halal certified food supply chain and extend the literature by showing the information that shared in supply chain.

In line with finding from I'pek Kocog lu et al.(2011), this research result shows retailer/distributor shared the information regarding demand forecast data with halal certified food manufacturers in Malaysia. The accurate demand forecast helps them to plan their inventory and distribution model.

The sharing information with supplier is also vital as mentioned in Zhang 2000 for the manufacturers to be highly competitive. However, halal certified food manufacturers has showed low information sharing with supplier. The uncertain relationship will hurt their business and hard for them to fulfil the demand from customers

They aware that they should have trust-based, transparent and strong relationships with their trading partners in order to share the information. They know that with useful information, they will be more competitive. However, there are few exceptional in the information sharing especially the information that gives advantage over competitors. Thus this research has added the literature by looking how trust should be encourage in halal food supply chain but there is still few information has to be kept.

\section{Conclusion}

Generally, the strategic relationships among members in supply chain, ought to be considered as the linkages constituting and sustaining a long-term common unity. Trust is the central goal of willingness to share the information. The finding shows that many cases in halal certified food manufacturers has very low communication with their supplier and low intensity of certainty with customer. They do not have meaningful relationship with the members in halal supply chain. Hence for improvement of information sharing, this research suggests the encouragement of using IT infrastructure by implementing real-time data transaction throughout the entire supply chain. Besides that, they should allow longterm, integrity and trust relationship with trading partners in halal food supply chain. This also show how halal certified food manufacturers try to have close relationship that are can be said as trustworthy partner. Setting internal and external meeting to review the relationship with trading partners in halal food supply chain.

This research is an explanatory of empirical data which required rich description of case information. The limitation of this research is that the sample is not entirely represent of all stages and business operation conducted in halal food supply chain. The data was gathered from four managers of halal certified food manufacturers in Malaysia that have limited range of products, the conclusion cannot be generalized to other countries or other sectors in Malaysia. Therefore, this opens to further research in this area. The recommendation of further research should involve suppliers and customers of halal food supply chain. Further research should look into what are the perception of information sharing from supplier, logistic provider and customer of halal food supply chain.

\section{Acknowledgement}

The author is grateful to Malaysian Ministry of Higher Education (MoHE) under Fundamental Research Grant Scheme (FRGS) to the Office of Research, Innovation, 
Commercialization and consultancy (ORICC) Universiti Tun Hussein Onn Malaysia (UTHM) under Vot 1430.

\section{References}

Bryman, A., \& Bell, E. (2015). Business research methods. Oxford University Press, USA.

Creswell, J. W. (2002). Educational research: Planning, conducting, and evaluating quantitative (pp. 146-166). Upper Saddle River, NJ: Prentice Hall.

Huang, G. Q., Lau, J. S., \& Mak, K. L. (2003). The impacts of sharing production information on supply chain dynamics: a review of the literature. International Journal of Production Research, 41(7), 1483-1517.

Koçoğlu, İ., İmamoğlu, S. Z., İnce, H., \& Keskin, H. (2011). The effect of supply chain integration on information sharing: Enhancing the supply chain performance. Procedia-Social and Behavioral Sciences, 24, 1630-1649.

Lee, H. L., Padmanabhan, V., \& Whang, S. (1997). The bullwhip effect in supply chains. Sloan management review, 38(3), 93.

Li, L., \& Zhang, H. (2008). Confidentiality and information sharing in supply chain coordination. Management science, 54(8), 1467-1481.

Seidman, I. Interviewing as qualitative research: A guide for researchers in education and the social sciences. 2006. New York and London: Teachers College, Columbia University Google Scholar.

Stake, R. E. (1995). The art of case study research. Sage.

Tan, K.H., Wong, W.P. and Chung, L. (2015), "Information and knowledge leakage in supply chain", Information Systems Frontiers, Vol. 18 No. 3, pp. 621-638.

Zsidisin, G. A., \& Ellram, L. M. (2003). An agency theory investigation of supply risk management. Journal of supply chain management, 39(2), 15-27. 